\title{
The effects of different spreader rates and fertilizer types on grain yields of barley (Hordeum vulgare L.)
}

\author{
1, ${ }^{*}$ Kakahy, A.N.N. ${ }^{2}$ Ahmad, D., ${ }^{3}$ Akhir, M.D. and ${ }^{4}$ Hashemi, A. \\ ${ }^{1}$ Department of Horticulture, Faculty of Agriculture, University of Kirkuk, Kirkuk, Iraq. \\ ${ }^{2}$ Department of Biological and Agricultural Engineering, Faculty of Engineering, Universiti Putra \\ Malaysia, 43400 UPM Serdang, Selangor, Malaysia. \\ ${ }^{3}$ Mechanization and Automation Research Center, MARDI, 43400 UPM Serdang, Selangor, Malaysia. \\ ${ }^{4}$ Department of Horticulture. Faculty of Agriculture and Natural Resources, Persian Gulf University. \\ Bushehr, Iran.
}

Article history:

Received: 21 May 2018

Received in revised form: 30

September 2018

Accepted: 5 October 2018

Available Online: 6

November 2018

Keywords:

Barely,

Fertilizers types,

Spreader rates,

Spike length,

Weight of grains.

\begin{abstract}
A field study was conducted to study the effects of three different spreader rates $(170,220$ and $270 \mathrm{~kg} \cdot \mathrm{ha}^{-2}$ ) and two fertilizer types [NPK and DAP (Diammonium Phosphate)] on the yield of barley crop (plant height $(\mathrm{cm})$, number of branches in plant (branch.plant ${ }^{-1}$ ), spike length $(\mathrm{cm})$, number of seeds.plant ${ }^{-1}$ (seeds.plant $\left.{ }^{-1}\right)$, number of spike. $\mathrm{m}^{-2}\left(\right.$ spike. $\left.^{-2}\right)$,

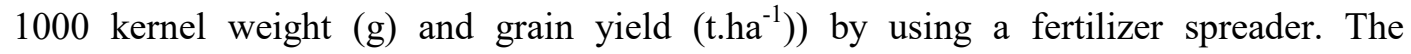
experiments were conducted in randomized complete block design (RCBD) with three replicates. The results of the study showed that the effects of the coefficients were ranged between significant and not significant concerning studied characteristics. It is recommended that using DAP fertilizer and $270 \mathrm{~kg} \cdot \mathrm{ha}^{-2}$ spreader rates to increase barley producing.
\end{abstract}

DOI:

https://doi.org/10.26656/fr.2017.3(2).102

\section{Introduction}

Barley (Hordeum vulgare L.) is a herbaceous plant that belongs to the grass family and it is one of the first planted grains (cultivated early as 10,000 years ago). It is now globally grown and ranked the fourth produced grain after corn, rice and wheat (Wakene et al., 2014). However, until now the yields of barley are very low in Iraq $\left(1.28\right.$ t.ha $\left.^{-1}\right)$ in 2014 compared with the average yields of developed countries such as France $\left(8.8\right.$ t.ha $\left.^{-1}\right)$, Germany (8.7 t.ha ${ }^{-1}$ ), Australia (7.9 t.ha ${ }^{-1}$ ), Russia (6.9 t.ha ${ }^{-1}$ ) and the United States $\left(3.4\right.$ t.ha $\left.^{-1}\right)$. Perhaps, the main reason for the decline in the average yield in Iraq is poor management of the crop (Faraj and Jaddoa, 2015). A study conducted by Al-freeh et al. (2015) for the effects of four seeding rates $(100,120,140$ and $160 \mathrm{~kg}$.ha ${ }^{1}$ ) and a number of cutting on growth and yield of Barley showed significant differences for seeding rates except for the weight of 1000 grain and seeding rate $120 \mathrm{~kg} \cdot \mathrm{ha}^{-1}$ gave the highest grain yield $\left(237 \mathrm{~kg} . \mathrm{m}^{-2}\right)$.

Hashem and Ali (2012) found that during two seasons of study (2009-2011), the highest means of grain yield (6.25 and 6.30 ton. $\mathrm{ha}^{-1}$ respectively) was at the rate of seeding $150 \mathrm{~kg} \cdot \mathrm{ha}^{-1}$ while with fertilizer treatment of
$249 \mathrm{~kg} \mathrm{k} \cdot \mathrm{ha}^{-1}$ gave the highest biological yield $(20.12$

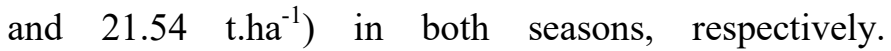
Interactions between the two factors caused significant effects and the authors recommend using the seeding rate of $150 \mathrm{~kg} \cdot \mathrm{ha}^{-1}$ and potassium level of $249 \mathrm{~kg} \mathrm{k} \cdot \mathrm{ha}^{-1}$ in order to have the highest means of grain yield (6.69 and 6.73 t.ha $^{-1}$ ) in both seasons, respectively. The barley is characterized by good organizational capacity as the basal branching in agriculture increases at the lowest rates and the number of branches of plants in agriculture at the highest rates. Satari et al. (2001) found that the best seed rate gives a high harvest index was $100 \mathrm{~kg} \cdot \mathrm{ha}^{-1}$ when studying three barley seed rates $(50,100$ and 150 kg.ha $\left.{ }^{-1}\right)$.

Sanaeifar and Sheikhdavoodi (2012) showed that increasing broadcasting rate due to increasing output flow rate of particles would decrease uniformity of broadcasting. Meanwhile, Refay (2009) noted that the highest yield of barley for two seasons (4.39 and 5.37 ton.ha ${ }^{-1}$ ) at the seed rate was $120 \mathrm{~kg} \cdot \mathrm{ha}^{-1}$ compared with the seed rate of $80 \mathrm{~kg} \cdot \mathrm{ha}^{-1}$. According to Bonachela et al. (1995) the determination of the optimum seed rate is one of the basic conditions for obtaining a high yield, because the reduction of the required limits may lead to 
the growth of large numbers of herbs that compete with barley in the early stages of growth through the lack of plants and to increase the number of seedlings, especially non-carriers, Is reflected negatively on the output of grain as a result of consumption of water and nutrients and not give them grains.

A study by Kovacevic and Kovacevic (2010) showed that increasing trend with fertilization by the fertilizer combination $\left(125 \mathrm{~N}+80 \mathrm{P}+120 \mathrm{~K} \mathrm{~kg} \cdot \mathrm{ha}^{-1}\right)$, thus the grain yield increased by the fertilized treatment gave 6.73 tons.ha ${ }^{-1}$ compared to the comparison treatment (without fertilization), which gave 5.42 tons. Khalil et al. (2011) found that the interaction between a seeding rate and $\mathrm{N}$ fertilizer $\left(150 \mathrm{~kg} \mathrm{ha}^{-1}, 160 \mathrm{~kg} \mathrm{~N} \mathrm{ha}^{-1}\right)$ respectively, gave the highest forage dry matter and biological yield of wheat. Meanwhile, grain yield was higher when $100 \mathrm{~kg}$ seed $\mathrm{ha}^{-1}$ plus $120 \mathrm{~kg} \mathrm{~N}^{-1}$ was used. Other researchers have reported that the interaction between seeding rate $\mathrm{N}$ fertilization rate $\left(600\right.$ seed $\mathrm{m}^{-2}$ and $\left.100 \mathrm{~kg} \mathrm{~N} \mathrm{ha}^{-1}\right)$, respectively, gave the highest barley production in grainonly and dual-purpose systems (Hajighasemi et al., 2016).

The objective of this study was to investigate the effects of different spreader rates and two fertilizer types on the yields of barley crop by using a fertilizer spreader.

\section{Materials and methods}

A field experiment was conducted at Kirkuk in Iraq during the season 2016-2017 to study the effects of three different spreader rates $(4,5,6)$ that were equal to $(170$, 220 and 270) kg.ha ${ }^{-2}$, respectively, and two granular fertilizer types, NPK (20:20:0) and DAP fertilizer (Diammonium Phosphate, (18-46-0)), on the yields of barley crop (plant height $(\mathrm{cm})$, number of branches in plant (branch.plant ${ }^{-1}$ ), spike length $(\mathrm{cm})$, number of seeds. plant ${ }^{-1}$ (seeds.plant ${ }^{-1}$ ), number of spike. $\mathrm{m}^{-2}$ (spike. $\mathrm{m}^{-2}$ ), 1000 kernel weight $(\mathrm{g})$ and grain yield $\left(\mathrm{t}^{-\mathrm{ha}^{-1}}\right)$ ) by using fertilizer spreader. The site is located at longitude $35.096464^{\circ} \mathrm{N}$, latitude $44.342383^{\circ} \mathrm{E}$ and an altitude of $196.0 \mathrm{~m}$ above sea level, and has a semi-arid climate (200-400 $\mathrm{mm}$ rainfall yearly). The land ploughed parallel twice by the mold board plough, followed by Disk plough to smoothing and settling the land, and then it was divided into slabs, opening the sails, and made the shoulders between the slabs. The experimental unit area $(2 \times 3) \mathrm{m}$ consisted of 10 lines and $20 \mathrm{~cm}$ between each line. The experimental design was a randomized complete block design (RCBD) with three replicates.

\subsection{Statistical analysis}

Analysis of variance (ANOVA) and L.S.D tests were used to analyse the data using the statistical analysis systems (SAS 12) software. The experiments were conducted in randomized complete block design (RCBD) with three replicates, data were analyzed statistically using ANOVA and the least significant difference (LSD) calculated at $\mathrm{p}>0.05$ and $\mathrm{p}>0.01$ to estimate the differences between the averages.

\section{Results and discussion}

No significant effects were found for the treatments on the plant height $(\mathrm{cm})$ (Tables 1 and 2). Meanwhile, there were significant effects at level $p>0.05$ for the spreader rates $(v 3=6)$ influencing on the number of branches in plant as shown in Tables 1 and 3 and Figure 1 , reaching 2.83 branches.plant $^{-1}$.

Tables 1 and 4 and Figures 2, 3 and 4 indicate that all the treatments had significant effects on the spike length at $p>0.01$, the highest spike length was by the DAP fertilizer (a2) of $7.66 \mathrm{~cm}$, although, the highest spike length was by the spreader rates (v3=6) of $7.82 \mathrm{~cm}$. The interactions between the fertilizer types and spreader rates had significant effects at $\mathrm{p}>0.05$, the highest spike length was by the interaction between DAP fertilizer and third spreader rates $(\mathrm{a} 2 \mathrm{v} 3)$ of $8.80 \mathrm{~cm}$, the lowest was for spike length was by the interaction between first fertilizer types (NPK) and second spreader rates (5) (a1v2) of $5.97 \mathrm{~cm}$.

Tables 1 and 5 and Figures 5 and 6 indicate that all the treatments had significant effects on the number of seeds at $\mathrm{p}>0.01$, the highest no. of seeds.plant ${ }^{-1}$ was by the DAP fertilizer (a2) and third spreader rates $(\mathrm{v} 3=6)$ of 50.44 and 57.67 no. of seeds. plant ${ }^{-1}$, alternately while the interactions between the fertilizer types and spreader rates had no significant effects.

Tables 1 and 6 and Figures 7,8 and 9 indicate that all the treatments had significant effects on the number of spike. $\mathrm{m}^{-2}\left(\right.$ spike. $\left.\mathrm{m}^{-2}\right)$ at $\mathrm{p}>0.01$, the highest spike. $\mathrm{m}^{-2}$ was by the DAP fertilizer (a2) of 956.44 spike. $\mathrm{m}^{-2}$, although, the highest spike. $\mathrm{m}^{-2}$ was by the spreader rates (v3=6) of 876.67 spike. $\mathrm{m}^{-2}$. The interactions between the fertilizer types and spreader rates had significant effects at $\mathrm{p}>0.05$, the highest spike. $\mathrm{m}^{-2}$ was by the interaction between DAP fertilizer and third spreader rates $(a 2 v 3)$ of 1133.33 spike. $\mathrm{m}^{-2}$, the lowest was for spike. $\mathrm{m}^{-2}$ was by the interaction between first fertilizer types (NPK) and first spreader rates (4) (a1v1) of 432.00 spike. $\mathrm{m}^{-2}$.

Tables 1 and 7 and Figures 10 and 11 indicate that all the treatments had significant effects on the 1000 kernel weight at $\mathrm{p}>0.01$, the highest 1000 kernel weight was by the DAP fertilizer (a2) and third spreader rates (v3=6) of (31.76 and 36.04) $\mathrm{g}$ of kernel weight, alternately while the interactions between the fertilizer 
Table 1. Analysis of variance (ANOVA) of the characteristics and components on the yield of barley.

\begin{tabular}{|c|c|c|c|c|c|c|c|c|}
\hline \multirow[b]{2}{*}{ S.O.V } & \multirow[b]{2}{*}{ d.f } & \multicolumn{7}{|c|}{ MS. } \\
\hline & & $\begin{array}{l}\text { Plant } \\
\text { height } \\
(\mathrm{cm})\end{array}$ & $\begin{array}{l}\text { No. of branches } \\
\text { in plant } \\
\text { (branch.plant }^{-1} \text { ) }\end{array}$ & $\begin{array}{l}\text { Spike } \\
\text { length } \\
(\mathrm{cm})\end{array}$ & $\begin{array}{l}\text { No. of seeds. } \\
\text { plant }^{-1} \\
\text { (seeds.plant }^{-1} \text { ) }\end{array}$ & $\begin{array}{c}\text { No. of } \\
\text { spike. } \mathrm{m}^{-2} \\
\left(\text { spike. } \mathrm{m}^{-2}\right)\end{array}$ & $\begin{array}{c}1000 \text { kernel } \\
\text { weight (g) }\end{array}$ & $\begin{array}{l}\text { Grain } \\
\text { yield } \\
\left(\text { t.ha }^{-1}\right)\end{array}$ \\
\hline Blocks & 2 & & & & & & & \\
\hline Treat. & 5 & & & & & & & \\
\hline A & 2 & $6.25^{\mathrm{n} . \mathrm{s}}$ & $0.111^{\mathrm{n} . \mathrm{s}}$ & $3.121^{* *}$ & $49^{* *}$ & $463307.1^{* *}$ & $19.407^{* *}$ & $2.8957^{* *}$ \\
\hline $\mathrm{V}$ & 1 & $3.111^{\mathrm{n} . \mathrm{s}}$ & $2.333^{*}$ & $5.203^{* *}$ & $968.778^{* *}$ & $209756.4^{* *}$ & $347.821^{* *}$ & $1.311^{* *}$ \\
\hline $\mathrm{AxB}$ & 2 & $50.667^{\mathrm{n} . \mathrm{s}}$ & $0.056^{\mathrm{n} . \mathrm{s}}$ & $1.004^{*}$ & $4.167^{\mathrm{n} . \mathrm{s}}$ & $7256.89^{*}$ & $1.611^{\mathrm{n} . \mathrm{s}}$ & $0.045^{* *}$ \\
\hline Error & 10 & 47.222 & 0.3 & 0.181 & 5.422 & 947.022 & 2.162 & 0.006 \\
\hline Total & 17 & & & & & & & \\
\hline L.S.D & $\mathrm{A}$ & n.s & n.s & 0.6795 & 3.7159 & 49.1086 & 2.3464 & 0.1228 \\
\hline$(\mathrm{p}>0.05$ and & V & n.s & 0.4679 & 0.5548 & 3.0340 & 40.0970 & 1.9159 & 0.1002 \\
\hline $\mathrm{p}>0.01)$ & $\mathrm{AxV}$ & n.s & n.s & 0.6300 & n.s & 45.5295 & n.s & 0.1736 \\
\hline
\end{tabular}

${ }_{\mathrm{n} . \mathrm{s}}=$ not significant, *significant at level $\mathrm{p}>0.05, * *$ significant at level $\mathrm{p}>0.01, \mathrm{M} . \mathrm{S}=$ mean square, a $=$ fertilizer types, $\mathrm{v}=$ spreader rates

Table 2. Factors influencing on the plant height $(\mathrm{cm})$

\begin{tabular}{ccccc}
\hline $\mathrm{a} / \mathrm{v}$ & $\mathrm{v} 1$ & $\mathrm{v} 2$ & $\mathrm{v} 3$ & Mean a \\
\hline $\mathrm{a} 1$ & 93.00 & 91.33 & 97.00 & 93.78 \\
$\mathrm{a} 2$ & 97.33 & 97.00 & 92.00 & 95.44 \\
\hline Mean v & 95.17 & 94.17 & 94.50 & \\
\hline
\end{tabular}

Table 3. Factors influencing on the number of branches in plant (branch.plant ${ }^{-1}$ )

\begin{tabular}{ccccc}
\hline $\mathrm{a} / \mathrm{v}$ & $\mathrm{v} 1$ & $\mathrm{v} 2$ & $\mathrm{v} 3$ & Mean a \\
\hline $\mathrm{a} 1$ & 3.67 & 2.67 & 3.00 & 3.11 \\
$\mathrm{a} 2$ & 3.33 & 2.67 & 2.67 & 2.89 \\
\hline Mean v & 3.50 & 2.67 & 2.83 & \\
\hline
\end{tabular}

Table 4. Factors influencing on the spike length $(\mathrm{cm})$

\begin{tabular}{ccccc}
\hline $\mathrm{a} / \mathrm{v}$ & $\mathrm{v} 1$ & $\mathrm{v} 2$ & $\mathrm{v} 3$ & Mean a \\
\hline $\mathrm{a} 1$ & 6.63 & 5.97 & 6.83 & 6.48 \\
$\mathrm{a} 2$ & 6.97 & 7.20 & 8.80 & 7.66 \\
\hline Mean v & 6.80 & 6.58 & 7.82 & \\
\hline
\end{tabular}

Table 5. Factors influencing on the number of seeds (no. of seeds.plant ${ }^{-1}$ )

\begin{tabular}{ccccc}
\hline $\mathrm{a} / \mathrm{v}$ & $\mathrm{v} 1$ & $\mathrm{v} 2$ & $\mathrm{v} 3$ & Mean a \\
\hline $\mathrm{a} 1$ & 38.33 & 43.67 & 55.33 & 45.78 \\
$\mathrm{a} 2$ & 41.33 & 50.00 & 60.00 & 50.44 \\
\hline Mean v & 39.83 & 46.83 & 57.67 & \\
\hline
\end{tabular}

Table 7. Factors influencing on the 1000 kernel weight (g).

\begin{tabular}{ccccc}
\hline $\mathrm{a} / \mathrm{v}$ & $\mathrm{v} 1$ & $\mathrm{v} 2$ & $\mathrm{v} 3$ & Mean a \\
\hline $\mathrm{a} 1$ & 24.42 & 27.46 & 34.58 & 28.82 \\
$\mathrm{a} 2$ & 26.33 & 31.45 & 37.50 & 31.76 \\
\hline Mean v & 25.37 & 29.45 & 36.04 & \\
\hline
\end{tabular}

$\mathrm{a}=$ fertilizer types, $\mathrm{v}=$ spreader rates

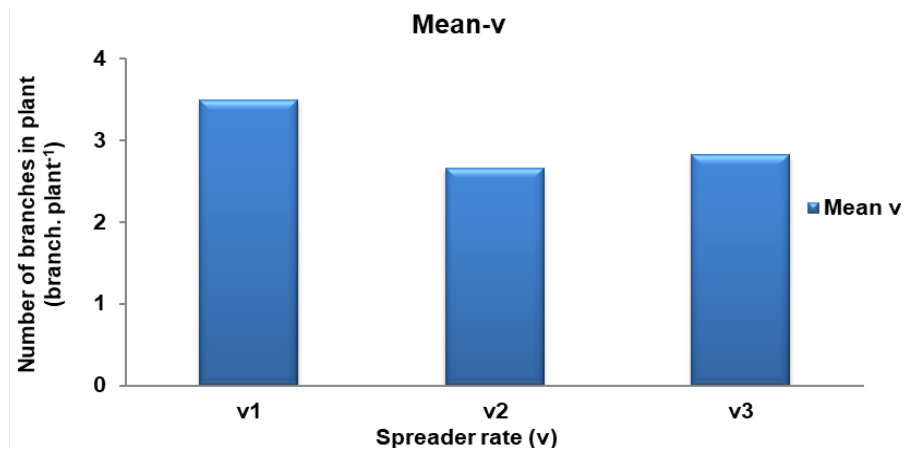

Figure 1. Spreader rate influencing on the number of branches in plant (branch.plant ${ }^{-1}$ )
Table 6. Factors influencing on the number of spike. $\mathrm{m}^{-2}$ (no. of spike. $\mathrm{m}^{-2}$ ).

\begin{tabular}{ccccc}
\hline $\mathrm{a} / \mathrm{v}$ & $\mathrm{v} 1$ & $\mathrm{v} 2$ & $\mathrm{v} 3$ & Mean a \\
\hline $\mathrm{a} 1$ & 432.00 & 456.00 & 620.00 & 502.67 \\
$\mathrm{a} 2$ & 809.33 & 926.67 & 1133.33 & 956.44 \\
\hline Mean v & 620.67 & 691.33 & 876.67 & \\
\hline
\end{tabular}

Table 8. Factors influencing on the grain yield (t.ha $\left.{ }^{-1}\right)$.

\begin{tabular}{ccccc}
\hline $\mathrm{a} / \mathrm{v}$ & $\mathrm{v} 1$ & $\mathrm{v} 2$ & $\mathrm{v} 3$ & Mean a \\
\hline $\mathrm{a} 1$ & 1.08 & 1.14 & 1.55 & 1.26 \\
$\mathrm{a} 2$ & 2.02 & 2.32 & 2.83 & 2.39 \\
\hline Mean v & 1.55 & 1.73 & 2.19 & \\
\hline
\end{tabular}

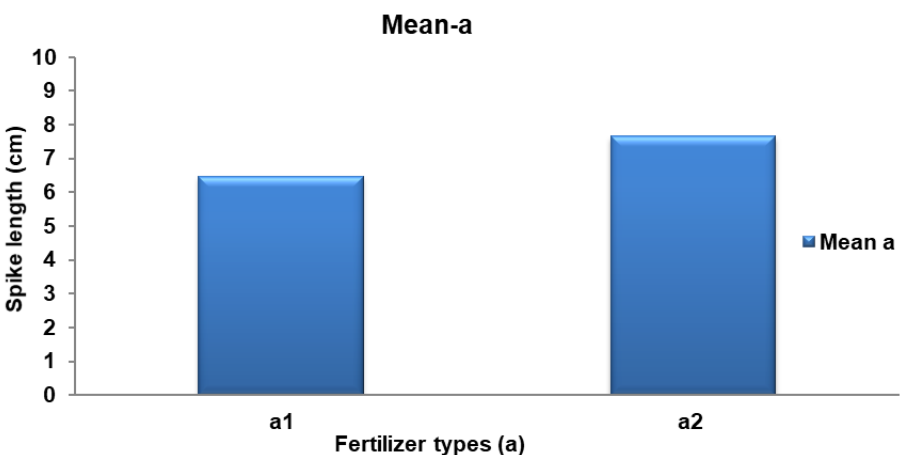

Figure 2. Fertilizer types influencing on the spike length $(\mathrm{cm})$. 


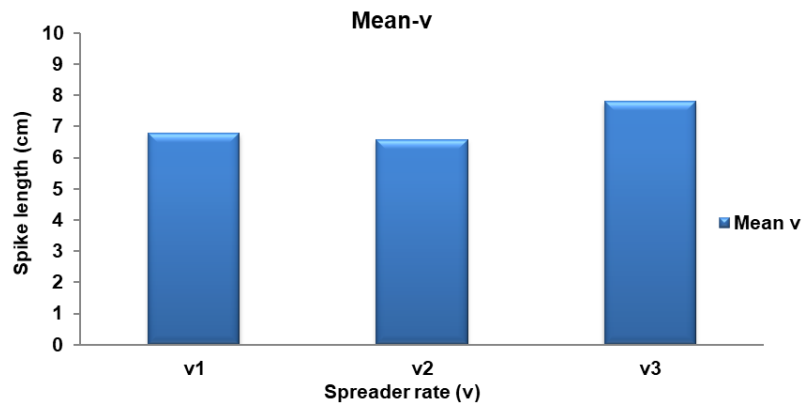

Figure 3. Spreader rate influencing on the spike length $(\mathrm{cm})$.

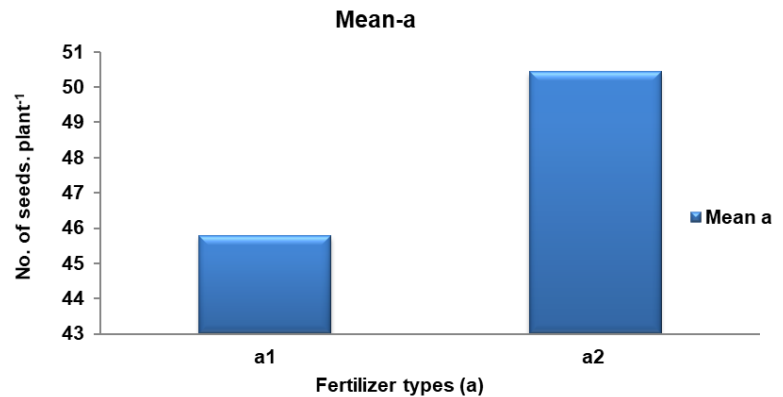

Figure 5. Fertilizer types influencing on the number of seeds (no. of seeds.plant ${ }^{-1}$ ).

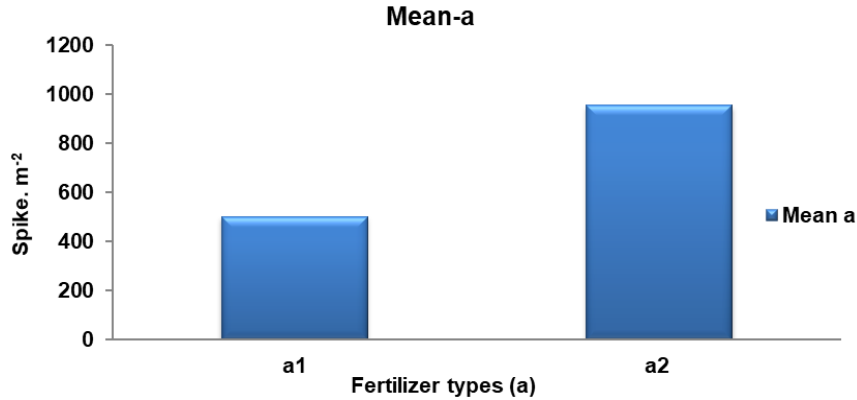

Figure 7. Fertilizer types influencing on the number of spike. $\mathrm{m}^{-2}$ (no. of spike. $\mathrm{m}^{-2}$ ).

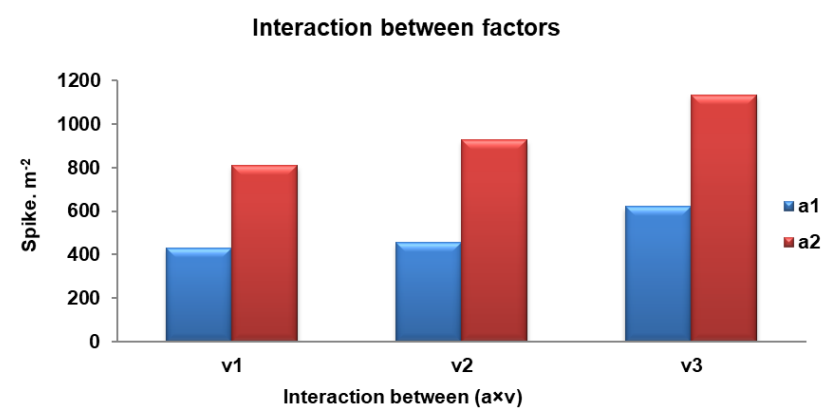

Figure 9. Interactions between the fertilizer types and spreader rates influencing on the number of spike. $\mathrm{m}^{-2}$ (no. of spike.m $\left.{ }^{2}\right)$.

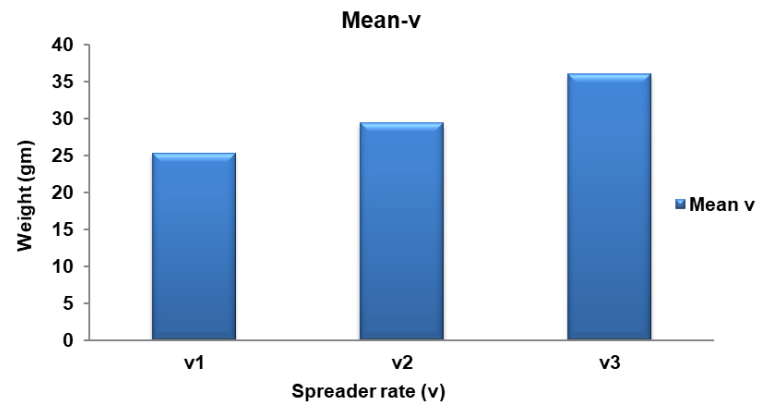

Figure 11. Spreader rate influencing on the 1000 kernel weight $(\mathrm{g})$.

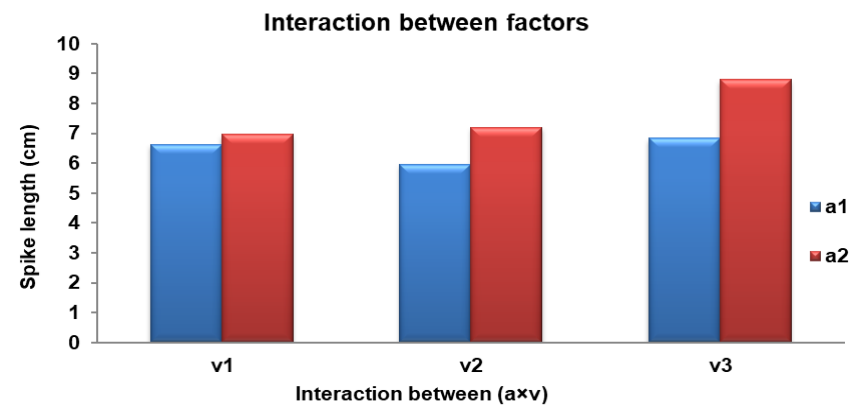

Figure 4. Interactions between the fertilizer types and spreader rates influencing on the spike length $(\mathrm{cm})$.

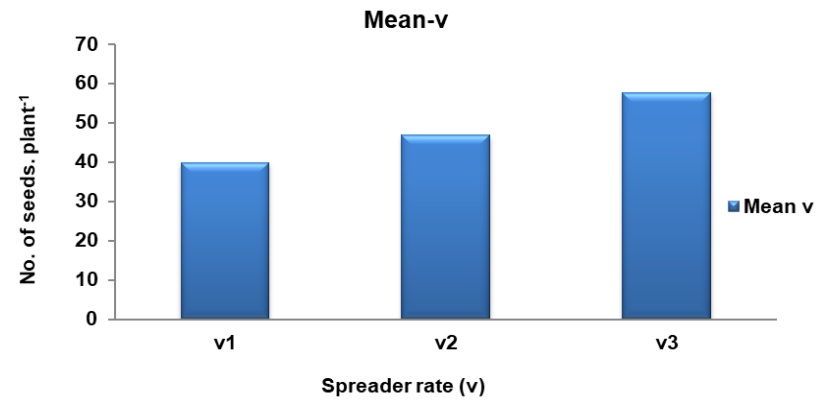

Figure 6. Spreader rate influencing on the number of seeds (no. of seeds.plant ${ }^{-1}$ ).

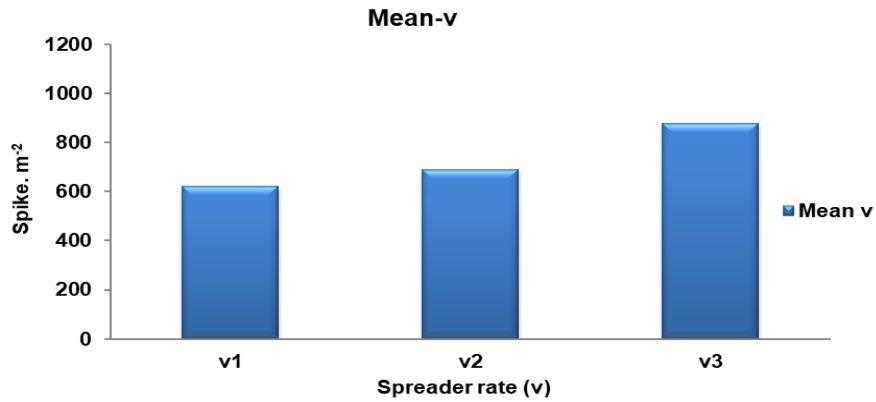

Figure 8. Spreader rate influencing on the number of spike. $\mathrm{m}^{-2}$ (no. of spike. $\mathrm{m}^{-2}$ ).

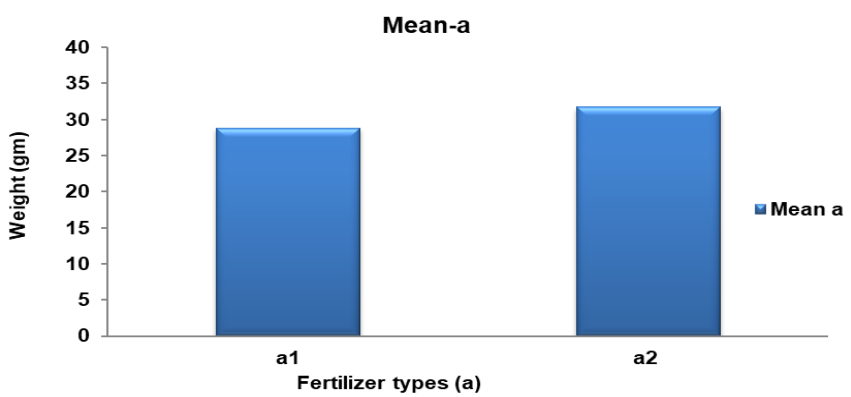

Figure 10. Fertilizer types influencing on the 1000 kernel weight $(\mathrm{g})$.

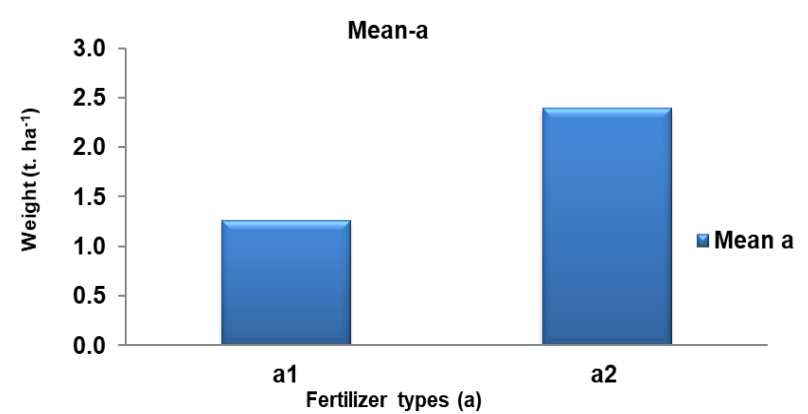

Figure 12. Fertilizer types influencing on grain yield (t.ha $\left.{ }^{-1}\right)$. 


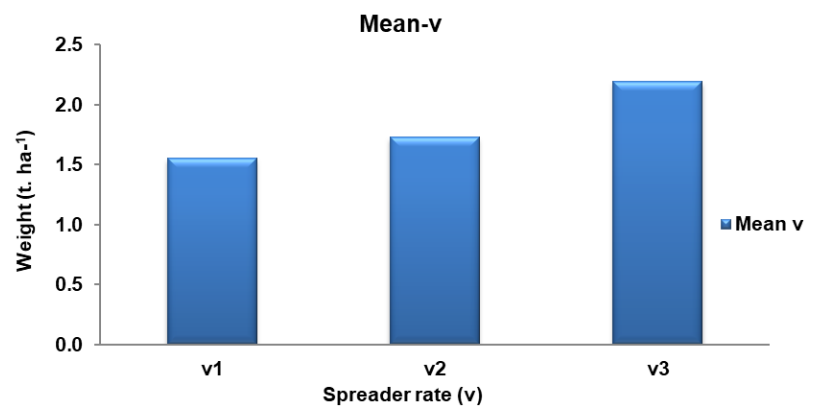

Figure 13. Spreader rate influencing on grain yield (t.ha $\left.{ }^{-1}\right)$.

types and spreader rates had no significant effects. So it is recommended that farmers could use any of fertilizers types and spreader rates to increase barley producing.

Tables 1 and 8 and Figures 12, 13 and 14 indicate that all the treatments had significant effects on the grain yield at $p>0.01$. The highest grain yield was by the DAP fertilizer (a2) of 2.39 t.ha $^{-1}$, while, the highest grain yield was by the spreader rates $(v 3=6)$ of $2.19 \mathrm{t}^{\mathrm{ha}} \mathrm{ha}^{-1}$. The highest grain yield was by the interaction between DAP fertilizer and third spreader rates $(\mathrm{a} 2 \mathrm{v} 3)$ of $2.83 \mathrm{t}^{\mathrm{ha}} \mathrm{h}^{-1}$, while the lowest was for grain yield by the interaction between first fertilizer types (NPK) and first spreader rates (4) (a1v1) of 1.08 t.ha $^{-1}$.

\section{Conclusion}

The best results were shown by the DAP fertilizer and level 6 spreader rates of $270 \mathrm{~kg} \cdot \mathrm{ha}^{-2}$. However, the effects of the coefficients were ranged between significant and not significant concerning studied characteristics. So it is recommended that farmers should use DAP fertilizer and $270 \mathrm{~kg} \cdot \mathrm{ha}^{-2}$ spreader rates to increase barley producing.

\section{Acknowledgements}

The authors would like to acknowledge the owner of the experiment field, S. Fatah, and all those who assisted.

\section{References}

Al-freeh, L.M., Obeidim R.H. and Al-Zergawy, M.A. (2015). Effect of seeding rates and number of cutting on growth and yield of Barley (Hordeum vulgare L.) in Basrah. Thi-Qar University Journal of Agricultural Researches, 4(2), 313-324

Bonachela, S., Orgaz, F. and Feres, E. (1995). Winter cereals grown for grain and for the dual purpose of forage plus grain I. Production. Field Crop Research, 44(1), 1-11. https://doi.org/10.1016/03784290(95)00045-1

Faraj, H.T. and Jaddoa, K.A. (2015). Effect of nitrogen levels and its application splitting on grain yield of barley (Hordeum vulgare L.). The Iraqi Journal of

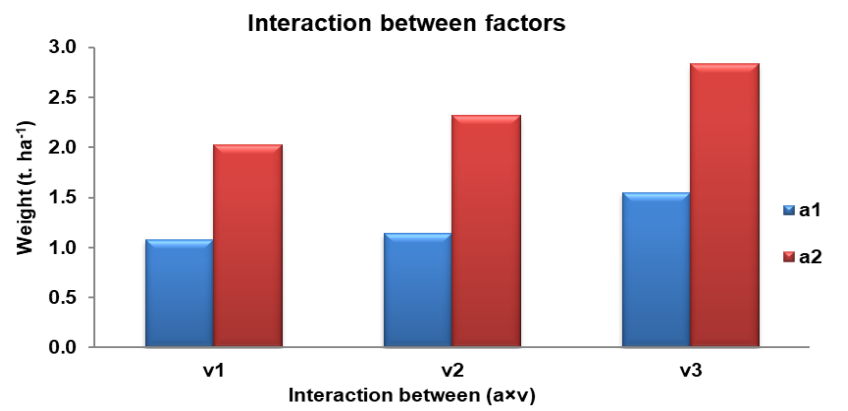

Figure 14. Interactions between the fertilizer types and spreader rates influencing on the grain yield $\left(\mathrm{t} \cdot \mathrm{ha}^{-1}\right)$.

Agricultural Sciences, 46(6), 934-942.

Hajighasemi, S., Keshavarz-Afshar, R. and Chaichi, M.R. (2016). Nitrogen Fertilizer and Seeding Rate Influence on Grain and Forage Yield of DualPurpose Barley. Agronomy Journal, 108(4), 14861494. https://doi.org/10.2134/agronj2015.0447

Hashem, M.H. and Ali, K.I.M. (2012). Effect of seeding rate and potassium on growth and yield of barley. The Iraqi Journal of Agricultural Sciences, 43(5), 33 -41 .

Khalil, S.K., Khan, F., Rehman, A., Muhammad, F.I.D.A., Amanullah, A.K., Khan, S.W. and Khan, H. (2011). Dual-purpose wheat for forage and grain yield in response to cutting, seed rate and nitrogen. Pakistan Journal of Botany, 43, 937-947.

Kovacevic, V. and Kovacevic, J. (2010). Response of malting winter barley to ameliorative NPKfertilization. The Journal of Agricultural Science, 42 (1), 138-142.

Refay, Y.A. (2009). Impact of soil moisture stress and seeding rate on yield variability of barley grown in arid environment of Saudi Arabia. AmericanEurasian Journal of Agronomy, 2(3), 185-191.

Sanaeifar, A. and Sheikhdavoodi, M.J. (2012). Evaluating of Broadcasting Uniformity of Centrifugal and Oscillating Granular Broadcasters. Research Journal of Applied Sciences, Engineering and Technology, 4(15), 2460-2468.

Satari, Y.A., Kafowin, O., Ghawi, J. and Saoub, H.M. (2001). Response of two barley cultivars to three seeding rates under supplemental irrigation. The Arab Gulf Journal of Scientific Research, 19(1), 711.

Tigre, W., Worku, W. and Haile, W. (2014). Effects of Nitrogen and Phosphorus Fertilizer Levels on Growth and Development of Barley (Hordeum vulgare L.) at Bore District, Southern Oromia, Ethiopia. American Journal of Life Sciences, 2(5), 260-266. https://doi.org/10.11648/ j.ajls.20140205.12. 